\title{
Live birth in a woman without ovaries after autograft of frozen-thawed ovarian tissue combined with growth factors
}

\author{
Justo Callejo ${ }^{{ }^{*}}$, Cristina Salvador ${ }^{1}$, Santiago González-Nuñez ${ }^{1}$, Laura Almeida', Luciano Rodriguez², Laura Marqués ${ }^{3}$,
} Ana Valls ${ }^{4}$ and José Maria Lailla ${ }^{1}$

\begin{abstract}
Currently, cryopreservation of oocytes, embryos and ovarian tissue is considered the basis of fertility preservation programs for women with cancer and other diseases who are rendered sterile by gonadotoxic drugs or radiation. Numerous studies have confirmed that autograft of frozen-thawed ovarian tissue can restore ovarian function and fertility. A total of twenty-two live births have been reported but we still have to consider this technique as experimental. The main problem is that the implant undergoes ischemia until neoangiogenesis is restored, resulting in significant follicular loss.

At the moment, there are numerous publications in different medical fields that publish successful experiences with plasma rich in platelets (PRP) in different clinical situations promoting angiogenesis. Thus, we considered the possibility of using it in the field of ovarian autologous transplantation in order to improve the vascularization of the implant and its quality. For this, both thawed ovarian tissue as practiced pockets on the rear side of the broad ligament which have been placed, have been impregnated with PRP. We can say that the implant treated in this way has had a rapid and successful response.

We report a special interesting case because this is the first time that this technique is performed successfully in a woman without ovaries combined with growth factors to promote neoangiogenesis. Obviously, the results of the hormonal response come exclusively from the implanted tissue in these special conditions.
\end{abstract}

Keywords: Platelet rich plasma, PRP, Antimüllerian hormone, AMH, Cryopreservation, Fertility preservation, Ovarian tissue transplantation

\section{Background}

Currently, cryopreservation of oocytes, embryos and ovarian tissue is considered the basis of fertility preservation programs for women with cancer and other diseases who are rendered sterile by gonadotoxic drugs or radiation.

Numerous studies have confirmed that autograft of frozen-thawed ovarian tissue can restore ovarian function and fertility. A total of twenty-two live births in twelve women have been reported [1-3], but this technique is still considered experimental. The main problem is that the implant undergoes ischemia until neoangiogenesis is restored,

\footnotetext{
* Correspondence: callejo@hsjdbcn.org

'Department of Obstetrics and Gynecology, Hospital Sant Joan de Déu,

Faculty of Medicine-University of Barcelona, Barcelona, Spain

Full list of author information is available at the end of the article
}

resulting in significant follicular loss as noted in some original articles [4-6].

We report a special interesting case because this is the first time that this technique is performed successfully in a woman without ovaries combined with growth factors to promote neoangiogenesis. Obviously, the hormonal response comes exclusively from the implanted tissue under these special conditions.

\section{Case presentation}

In 2001, when the patient was 20 years old, she underwent an urgent left oophorectomy due to a twisted necrosed dermoid cyst of $15 \times 10 \mathrm{~cm}$. After two months, in the postsurgical control, the ultrasound examination showed another cyst of $3 \times 2 \mathrm{~cm}$ in the right ovary that again suggested a dermoid cyst. A new surgery was proposed to the patient

\section{Biomed Central}


with a conservative intention but after the cystectomy only $25 \%$ of healthy ovarian tissue was left and it was emplaced opposite to the vascular hilum and connected to it by just a fibrous band with poor vascularization. Therefore, we proceeded to resect and cryopreserve the remained tissue according to the fertility preservation protocol in oncological patient of our hospital. The patient was informed of this eventuality. The anathomo-pathologycal analysis confirmed the clinical diagnosis of dermoid cyst in both tumors.

Clinical and biochemical premature ovarian insufficiency (POI) was immediately observed; therefore, hormonal replacement treatment (HRT) was started.

In 2011, when she was 30 years old, the patient wished to become pregnant. HRT was stopped and the cryopreserved ovarian tissue was reimplanted using growth factors to boost neoangiogenesis. Four-and-a half months later, the ovarian function was restored and the first spontaneous menstruation ensued. Then, on the third day of menstrual bleeding, ovarian stimulation for in vitro fertilization/ intracytoplasmatic sperm injection (IVF/ICSI) was started. In each implant one follicle $6 \mathrm{~mm}$ developed. Peripheral hormones showed the following levels: follicular stimulating hormone (FSH) 7,9 mIU/ml; and estradiol $58 \mathrm{pg} / \mathrm{ml}$. We used 300 units of recombinant FSH daily and on the third day we added 150 units of recombinant luteinizing hormone (LH), also daily (Gonal-F and Luveris, Merk Serono). On day 6 of the stimulation, a daily administration of $0.25 \mathrm{mg}$ of a gonadotropin releasing hormone (GnRH) antagonist (Cetrotide, Merck Serono) was initiated. On the ninth day of stimulation egg retrieval was performed. Estradiol levels were $316 \mathrm{pg} / \mathrm{ml}$. The ovulation was triggered with human chorionic gonadotropin (HCG) $250 \mathrm{mcg}$ (Ovitrelle, Merck Serono) followed by vaginal administration of $200 \mathrm{mg}$ micronized progesterone 3 times a day (Utrogestan, Laboratorios SEID S.A.) and estradiol hemihydrate $0.78 \mathrm{mg}$ transdermal every three days (Estradot, Novartis Farmaceutica). The endometrial thickening was $10 \mathrm{~mm}$, and 3 follicles were retrieved (two $14 \mathrm{~mm}$ on the right side and one $11 \mathrm{~mm}$ on the left side). Two oocytes were obtained, one metaphase II (MII) and the other metaphase I (MI) that developed to MII after 7 hours of culture). Both were inseminated by ICSI. On the day +2 we transferred a 4 regular mononucleated cells embryo and the other with $15 \%$ of fragmentation. Serum testing for HCG was positive 13 days after the embryo transfer. Repeated ultrasonography during the pregnancy showed normal fetal growth and development. At 38 weeks and 6 days of gestation, a healthy boy weighing $3.500 \mathrm{Kg}$, Apgar 9-10, was delivered by caesarean section on July 31, 2012.

\section{Freezing and thawing of ovarian tissue}

Ovarian tissue was frozen in pieces of $2-3 \mathrm{~mm}^{3}$ using dimethylsulphoxide (DMSO) and thawed according to the protocol described elsewhere by our group [7].

\section{Platelet rich plasma (PRP)}

Platelet rich plasma was prepared starting with $60 \mathrm{~mL}$ of patient's blood drawn into tubes containing $3.2 \%$ of citratated dextrose. Blood was centrifuged at $280 \mathrm{~g}$ for 15 minutes at room temperature, plasmatic fraction was isolated and a second centrifugation was performed at $680 \mathrm{~g}$ during 20 minutes. The platelet pellet was diluted

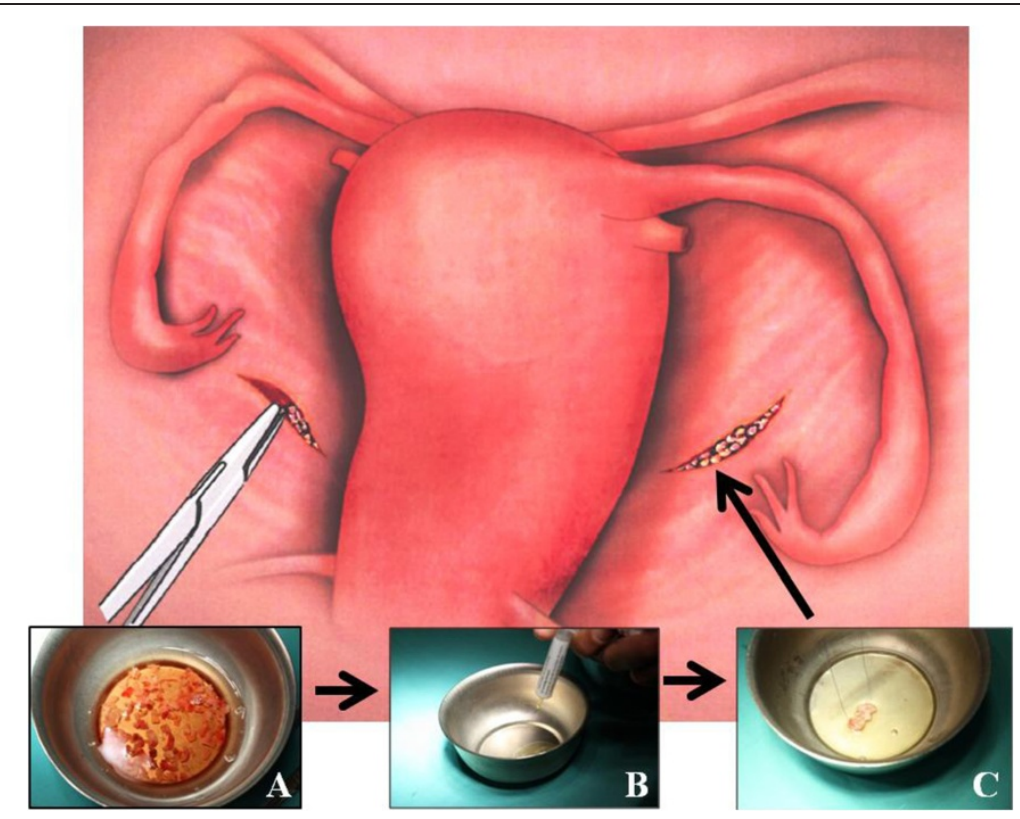

Figure 1 The surgical procedure is extremely easy. The thawed ovarian tissue (A) is impregnated in a gel preparation of PRP (B) and it is transferred using laparoscopic surgery to the pockets located in the posterior surface of the broad ligaments (C). 
in $5 \mathrm{~mL}$ of autologous plasma. Finally, the ovarian tissue was coated with PRP before implantation.

Multiple preparations of PRP for clinical use have been described. Differences in volume, concentration of platelets, white blood cells and even in the final presentation (liquid or gel) define the observed variability of those products. We performed a double-spin centrifugation protocol to obtain the highest recovery of platelets to promote a rapid neovascularization of the graft $[8,9]$ but with the minimal concentration of blood cells to avoid undesirable catabolic and inflammatory related events that could potentially affect the ovarian tissue $[10,11]$.

\section{Surgery}

For the reimplantation we used all the frozen-thawed small cubes of ovarian tissue $\left(1-2 \mathrm{~mm}^{3}\right)$. We created a peritoneal pocket in both posterior surfaces of the broad ligament by laparoscopic surgery, where we placed the cubes. Previously, we used a gel preparation of PRP to impregnate the cubes and, after they have been located in the peritoneal pockets performed, it proceeds to fill these with the platelet gel using the $5 \mathrm{~mL}$ supplied (Figure 1).

\section{Hormone laboratory}

Serum FSH, LH and HCG were measured by a chemiluminiscent microparticle immunoassay in an ARCHITECT analyzer (Abbott Laboratories, Abbott Park, IL). Progesterone was measured by a Chemiluminescent enzyme immunoassay in a IMMULITE2000 analyzer, SIEMENS Healthcare Diagnostics. Anti-Mullerian Hormone (AMH)

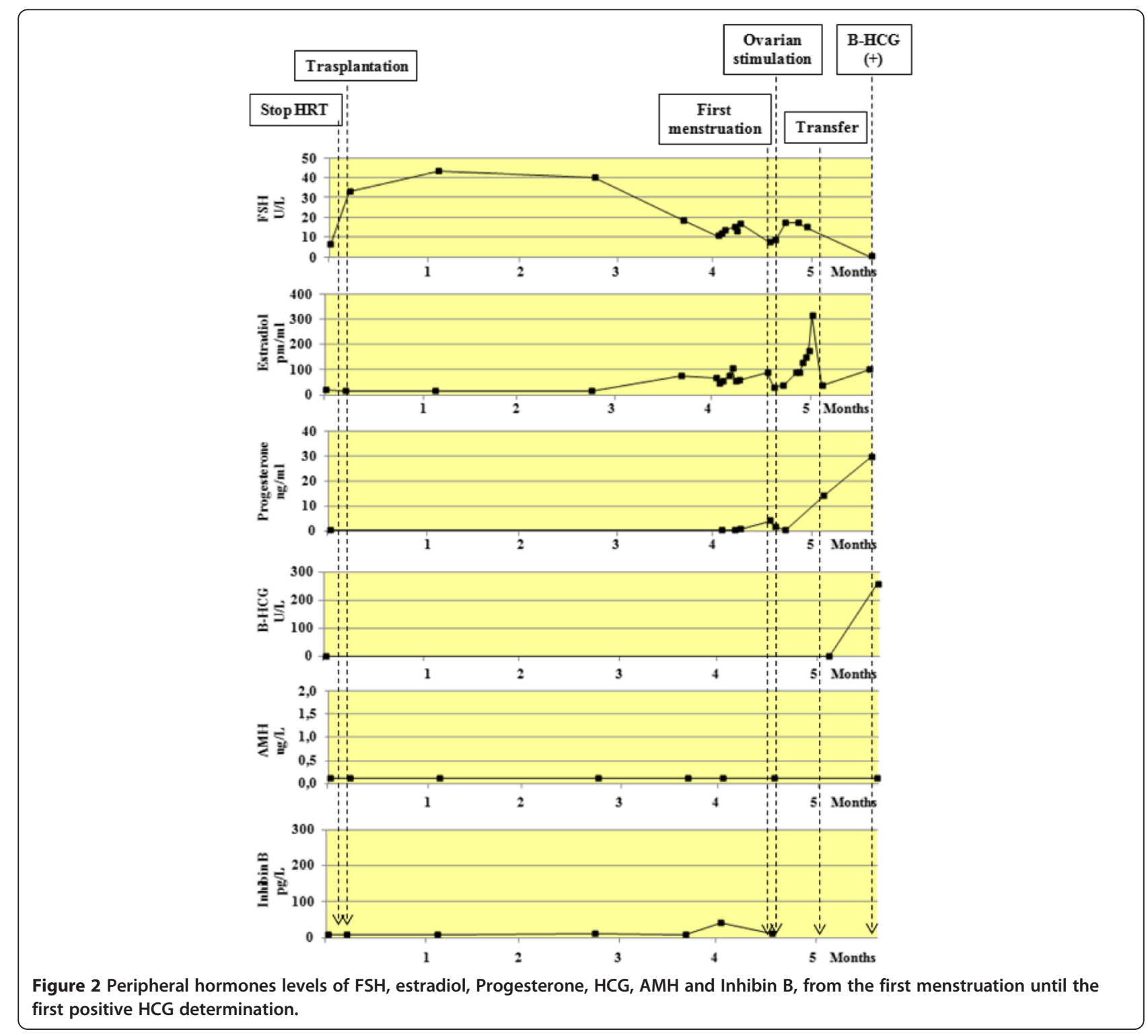


serum was measured using an ultrasensitive two-site ELISA (BECHMAN COULTER, USA). Serum inhibin B concentrations were measured using a highly sensitive two-site enzymelinked immunosorbent assay ELISA; (Diagnostic Systems Laboratories, Inc).

\section{Ethical considerations}

The protocol was approved by the local Ethical Committee and the administrative authorization Ref. H08000875 Departament de Salut (Generalitat de Catalunya). The patient and her partner received written information about all the process and signed the informed consent.

\section{Results}

Figure 2 shows the peripheral hormones levels of $\mathrm{FSH}$, estradiol, Progesterone, HCG, AMH and Inhibin B, from the first menstruation until the first positive HCG determination. Figure 3 shows the hormonal changes during pregnancy and immediate postpartum.

\section{Discussion}

Certainly, the main problem of autograft of frozenthawed ovarian tissue is the loss of more than $50 \%$ of follicles caused by the ischemia that the autograft suffers until neoangiogenesis is restored [4-6]. Today, investigators are working to improve this problem.

PRP is a blood product where a high level of platelets is concentrated (about 1.000 .000 of platelets $/ \mu \mathrm{L}$ in $5 \mathrm{ml}$ of plasma) but with growth factors concentration 3 to 5 times greater than plasma. Growth factors are stored in $\alpha$ granules, and include platelet derivated growth factor (PDGFs), Transforming growth factor-beta (TGF- $\beta$ ), vessel endothelial growth factor (VEGF), epidermal growth factor (EGF), fibroblast growth factor (FGF) e insulinelike growth factor (IGF) and some others [12,13]. These cytokines play an important role in cellular proliferation, chemotaxis and differentiation of mesenchymal and other cells and promote angiogenesis [13].

There are already numerous publications in different medical fields reporting successful experiences with PRP that improve neoangiogenesis in different clinical situations

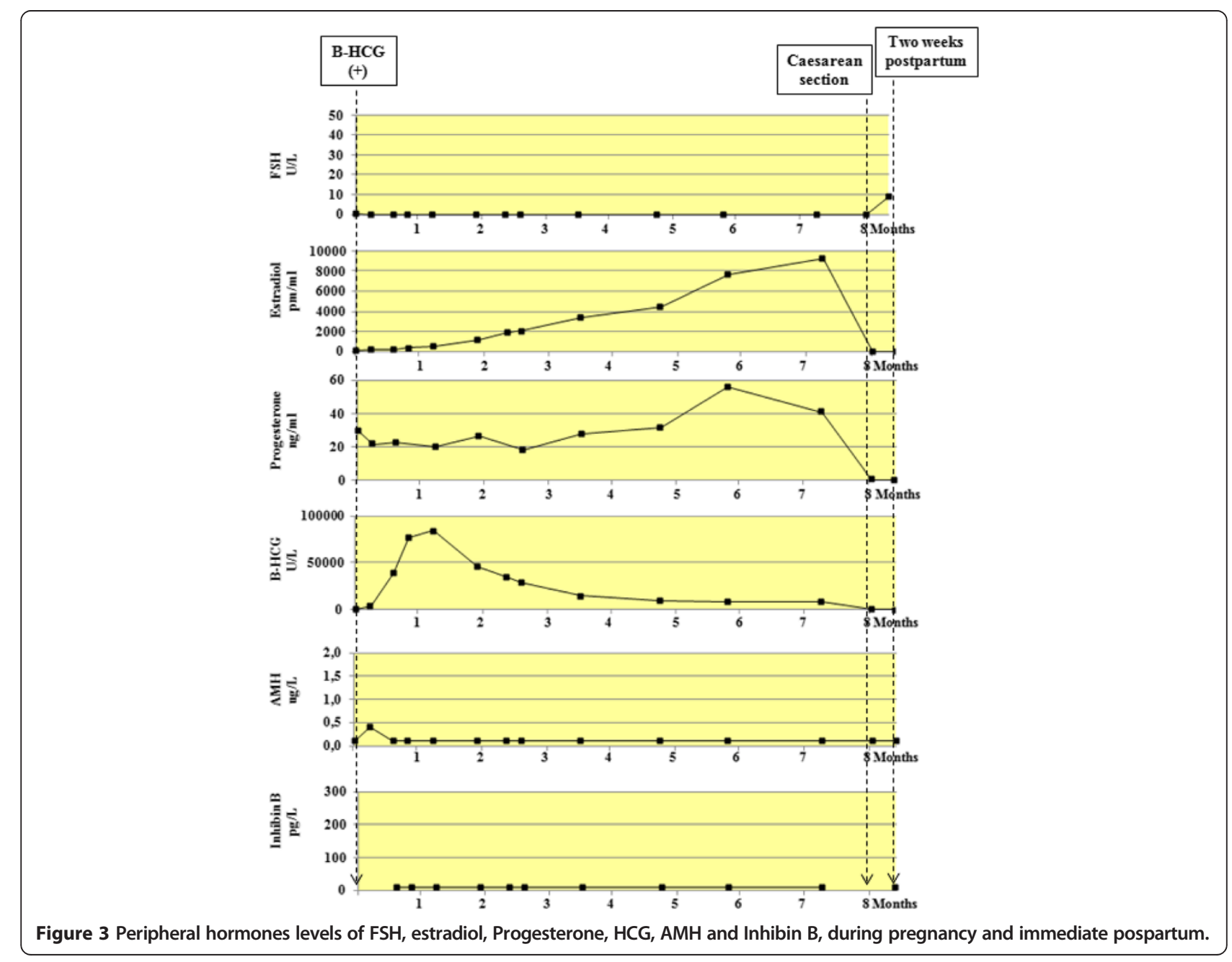


[8-16]. Thus, we considered the possibility of using it in the field of ovarian autologous transplantation in order to improve the vascularization of the implant and its quality.

The result has been successful in obtaining a healthy baby in the first cycle of stimulation, but it has been seen before $[17,18]$ without the use of PRP. But with a single case, one cannot draw any conclusions. More studies are required to determine whether the use of PRP represents a contribution.

We would like to highlight the results of the levels of $\mathrm{AMH}$ : throughout the process, peripheral levels of this hormone were undetectable $(<0.1 \mathrm{ng} / \mathrm{ml})$. These results are consistent with the series of Janse et al. [19] and Grave et al. [20]. Very low or undetectable levels of $\mathrm{AMH}$ at the time of conception indicate a poor and irregular pool of them which have already started their development from primordial follicles.

We would like to make some observations on the indication of egg retrieval when follicle sizes are about 1415 millimeters. Usually, these can be considered immature follicles, moreover if we obtain levels of estradiol that correspond to a mature follicle in transplanted patients with this follicular size $(14-15 \mathrm{~mm})$, we should consider that indirect clinical criteria of follicular maturity in the autograft (follicular size and rate of estradiol), do not necessarily have to be the same as in the normal inserted ovary. When we perform ultrasound measurements of the follicles we are measuring the antral diameter without considering the possibility of a granulosa layer hyperplasia that provides estradiol characteristic levels of a mature follicle. In the experimental model, when the reimplanted ovarian tissue is functioning, our group shows this possibility [21,22].

At this point we would like to draw attention on the recommendations of Oktay et al. in 2004 [23] who proposed follicular maturity at a size of $10-11 \mathrm{~mm}$ in this type of tissue. Demesteere et al. [24] who reported a spontaneous pregnancy after orthotopic graft in 2006, explains that the follicles which developed in the subcutaneous implant never reached the sufficient size to be retrieved (maximum $13 \mathrm{~mm}$ ). A year later, the same author [25], in the second reimplantation to the same patient, which fortunately concluded with the announcement of the third live birth from cryopreserved ovarian tissue, announced that the two retrieved follicles of the implanted ovarian measured $15 \mathrm{~mm}$ at the time of ovulation. Fourteen days later chorionic gonadotropin levels were detected.

Nevertheless, many authors have retrieved follicles above $17 \mathrm{~mm}$ obtaining good quality MII oocytes [1] and these arguments must consider only speculation.

\section{Conclusion}

We report the second pregnancy occurred after ovarian tissue cryopreservation for benign ovarian pathology after bilateral oophorectomy. Growth factors are used in combination with frozen-thawed ovarian tissue to boost neoangiogenesis. The result of this case was successful. However, more studies are required to determine whether the use of PRP represents a contribution.

\section{Consent}

Written informed consent was obtained from the patient for publication of this Case Report and any accompanying images. A copy of the written consent is available for review by the Editor-in-Chief of this journal.

\section{Abbreviations}

PRP: Platelet rich plasma; AMH: Antimullerian hormone; POI: Premature ovarian insufficiency; HRT: Hormonal replacement treatment; IVF: in vitro fertilization; ICSI: Intracytoplasmic sperm injection; FSH: Follicle stimulating hormone; LH: Luteinizing hormone; GnRH: Gonadotropin-releasing hormone; HCG: Human chorionic gonadotropin; MIl: Metaphase II; MI: Metaphase I; DMSO: Dimethyl sulfoxide; PDGF: Platelet derivate growth factor; TGF$\beta$ : Transforming growth factor-beta; VEGF: Vessel endothelial growth factor; EGF: Epidermal growth factor; FGF: Fibroblast growth factor; IGF: Insuline-like growth factor.

\section{Competing interests}

The authors declare that they have no competing interests.

\section{Authors' contributions}

JC has conceived the study, participated in its design and coordination and he has drafted the manuscript; CS has been involved in drafting the manuscript and revising it critically for important intellectual content; SG-N has been performed the surgical intervention; LA has participated in the design of the study and drafted the manuscript; LR has carried the preparation of PRP and drafted the manuscript; LM has carried out laboratory the work in the human reproduction laboratory; AV has carried out the hormone assays and drafted the manuscript, and JML has given final approval of the version to be published. All authors have read and approved the final manuscript.

\section{Authors' information}

From Department of Obstetrics and Gynecology, Hospital Sant Joan de Déu; Faculty of Medicine-University of Barcelona, Barcelona, Spain (J.C., C.S., S.G.N., L.A. J.M.L.); Tissues Bank Division, Banc de Sang i Teixits, Barcelona, Spain (L.R.); Center for Human Reproduction, Clínica Sagrada Familia, Barcelona, Spain (L.M.) and Hormone Laboratory, Hospital Sant Joan de Déu, Barcelona, Spain (A.V.)

\section{Author details}

'Department of Obstetrics and Gynecology, Hospital Sant Joan de Déu, Faculty of Medicine-University of Barcelona, Barcelona, Spain. ${ }^{2}$ Tissues Bank Division, Banc de Sang i Teixits, Barcelona, Spain. ${ }^{3}$ Center for Human Reproduction, Clínica Sagrada Familia, Barcelona, Spain. ${ }^{4}$ Hormone Laboratory, Hospital Sant Joan de Déu, Barcelona, Spain.

Received: 13 February 2013 Accepted: 30 April 2013 Published: 7 May 2013

\section{References}

1. Donnez J, Jadoul P, Pirard C, Hutchings G, Demylle D, Squifflet J, Smitz J, Dolmans MM: Live birth after transplantation of frozen-thawed ovarian tissue after bilateral oophorectomy for benign disease. Fertil Steril 2012, 98(3):720-725.

2. Revelli A, Marchino G, Dolfin E, Molinari E, Delle Piane L, Salvagno F, Benedetto C: Live birth after orthotopic grafting of autologous cryopreserved ovarian tissue and spontaneous conception in Italy. Fertil Steril 2013, 99(1):227-230.

3. Isachenki V, Isachenki E, Keck G, Dittrich R, Montag M, van der Ven $H$, Mallmann P, Müller A, Distler W, Beckmann MW, Rahimi G: First live birth in Germany after re-transplantation of cryopreserved ovarian 
tissue: original device for initiation of ice formation. Clin Lab 2012, 58(9-10):933-938.

4. Baird DT, Webb R, Campbell BK, Harkness LM, Gosden RG: Long-term ovarian function in sheep after ovariectomy and transplantation of autografts stored at -196 C. Endocrinology 1999, 140(1):462-471.

5. Nisolle M, Casanas-Roux F, Qu J, Motta P, Donnez J: Histologic and ultraestructural evaluation of fresh and frozen-thawed human ovarian xenografts in nude mice. Fertil Steril 2000, 74(1):122-129.

6. Donnez J, Dolmans MM, Demylle D, Jadoul P, Pirard C, Squifflet J, Martinez-Madrid B, van Langendonckt A: Restoration of ovarian function after orthotopic (intraovarian and periovarian) transplantation of cryopreserved ovarian tissue in a woman treated by bone marrow transplantation for sickle cell anaemia: case report Hum Reprod 2006, 21:183-188.

7. Callejo J, Salvador C, Miralles A, Vilaseca S, Lailla JM, Balasch J: Long-term ovarian function evaluation after autografting by implantation with fresh and frozen-thawed human ovarian tissue. J Clin Endocrinol Metab 2001, 86:4489-4494

8. Bosch G, Moleman M, Barneveld A, van Weeren PR, van Schie HT: The effect of platelet-rich plasma on the neovascularization of surgically created equine superficial digital flexor tendon lesions. Scand J Med Sci Sports 2011, 21(4):554-561.

9. Roy S, Driggs J, Elgharably H, Biswas S, Findley M, Khanna S, Gnyawali U, Bergdall VK, Sen CK: Platelet-rich fibrin matrix improves wound angiogenesis via inducing endothelial cell proliferation. Wound Repair Regen 2011, 19(6):753-766.

10. El-Sharkawy H, Kantarci A, Deady J, Hasturk H, Liu H, Alshahat M, van Dyke TE: Platelet-rich plasma: growth factors and pro- and anti-inflammatory properties. J Periodontol 2007, 78(4):661-669.

11. Sundman EA, Cole BJ, Fortier LA: Growth factor and catabolic cytokine concentrations are influenced by the cellular composition of platelet-rich plasma. Am J Sports Med 2011, 39(10):2135-2140.

12. Anitua E, Andia I, Ardanza B, Nurden AT: Autologous platelets as a source of proteins for healing and tissue regeneration. Thromb Haemost 2004 92:1-12.

13. Foster TE, Puskas BL, Mandelbaum BR, Gerhardt MB, Rodeo SA: Platelet-Rich Plasma: From Basic Science to Clinical Applications. Am J Sports Med 2009, 37:2259-2263.

14. Anitua $\mathrm{E}$, Alkhraisat MH, Orive G: Perspectives and challenges in regenerative medicine using plasma rich in growth factors. $J$ Control Release 2012 Jan 10, 157(1):29-38.

15. Yu W, Wang J, Yin J: Platelet-rich plasma: a promising product for treatment of peripheral nerve regeneration after nerve injury. Int $\mathrm{J}$ Neurosci 2011, 121(4):176-180.

16. Everts PA, Hoogbergen MM, Weber TA, Devilee RJ, van Monftort G, de Hingh $\mathbb{H}$ Is the Use of Autologous Platelet-Rich Plasma Gels in Gynecologic, Cardiac, and General, Reconstructive Surgery Beneficial? Curr Pharm Biotechnol 2011, 13(7):1163-1172.

17. Andersen CY, Rosendahl M, Byskov AG, Loft A, Ottosen C, Dueholm M, Schmidt $\mathrm{KL}$, Andersen AN, Ernst E: Two successful pregnancies following autotransplantation of frozen/thawed ovarian tissue. Hum Reprod 2008, 23(10):2266-2272.

18. Meirow D, Levron J, Eldar-Geva T, Hardan I, Fridman E, Zalel Y, Schiff E, Dor J: Pregnancy after transplantation of cryopreserved ovarian tissue in a patient with ovarian failure after chemotherapy. N Engl J Med 2005, 353(3):318-321.

19. Janse F, Donnez J, Anckaert E, de Jong FH, Fauser BC, Dolmans MM: Limited value of ovarian function markers following orthotopic transplantation of ovarian tissue after gonadotoxic treatment. J Clin Endocrinol Metab 2011, 96:1136-1144.

20. Greve T, Schmidt K, Kristensen SG, Ernst E, Andersen CY: Evaluation of the ovarian reserve in women transplanted with frozen and thawed ovarian cortical tissue. Fertil Steril 2012, 97:1395-1398.

21. Callejo J, Vilaseca S, Ordi J, Cabré S, Lailla JM, Balasch J: Heterotopic ovarian transplantation without vascular pedicle in syngeneic Lewis rats: long-term evaluation of effects on ovarian structure and function. Fertil Steril 2002, 77(2):396-402

22. Callejo J, Vilaseca S, Medina M, Salvador C, Valls C, Lailla JM: Inhibin and follicle development in heterotopical transplant of ovary without vascular pedicle in syngeneic Lewis rats. Fertil Steril 2003, 79(1):743-748.
23. Oktay K, Buyuk E, Veeck L, Zaninovic N, Xu K, Takeuchi T, et al: Embryo development after heterotopic transplantation of cryopreserved ovarian tissue. Lancet 2004, 363(9412):837-840.

24. Demeestere I, Simon P, Buxant F, Robin V, Fernandez Aguilar S, Centner J, Delbaere A, Englert Y: Ovarian function and spontaneous pregnancy after combined heterotopic and orthotopic cryopreserved ovarian tissue transplantation in a patient previously treated with bone marrow transplantation. Hum Reprod 2006, 21(8):2010-2014.

25. Demeestere I, Simon P, Emiliani S, Delbaere A, Englert Y: Fertility preservation: Successful transplantation of cryopreserved ovarian tissue in a young patient previously treated for Hodgkin's disease. Oncologist 2007, 12:1437-1442.

doi:10.1186/1757-2215-6-33

Cite this article as: Callejo et al: Live birth in a woman without ovaries after autograft of frozen-thawed ovarian tissue combined with growth factors. Journal of Ovarian Research 2013 6:33.

\section{Submit your next manuscript to BioMed Central and take full advantage of:}

- Convenient online submission

- Thorough peer review

- No space constraints or color figure charges

- Immediate publication on acceptance

- Inclusion in PubMed, CAS, Scopus and Google Scholar

- Research which is freely available for redistribution 